\title{
UJI EFEK ANALGESIK \\ EKSTRAK DAUN PEPAYA (Carica pepaya (L.)) \\ PADA MENCIT (Mus musculus)
}

\author{
${ }^{1}$ Agnesi Lasarus \\ ${ }^{2}$ Johanis A. Najoan \\ ${ }^{2}$ Jane Wuisan \\ ${ }^{1}$ Kandidat Fakultas Kedokteran Unsrat \\ ${ }^{2}$ Bagian Farmakologi dan Terapi Fakultas Kedokteran Universitas Sam Ratulagi \\ Email: agnesilasarus@ymail.com
}

\begin{abstract}
Background : The natural medicine has been known and used throughout of the world for thousands of the years. One of them is papaya. efficacy papaya leave provide efficacy as fever, appetite enhancer, launsed menstruation and relieve pain. This study aims to determine whether the extract of papaya leaves have analgesic effects on mice by using the method of thermal stimulation. Methods: This study is an experimental study using nine mice. This animals were divided into three groups where each group consisting of three mice. Papaya leaves, tramadol, and aquades were give to each group as test substances and comparative solution. Observations were carried out for 1 minute using the method of thermal stimulation was a decreases of protection mechanism of the mice in of licking and or flicking responses after the administration of test substances. Results: There was a decrease of the response of mice to lick feet and or jump to the heat stimuli were given after administration of papaya leaf extract. Conclusion: The extract of papaya leaves has an analgesic effect on mice.
\end{abstract}

Keywords: Analgesic, papaya leaf extract, heat stimulation

\begin{abstract}
Abstrak: Latar Belakang: Tanaman obat sudah dikenal dan digunakan di seluruh dunia sejak beribu tahun yang lalu. Salah satu jenis tanaman obat yang sering digunakan yaitu pepaya. Khasiat daun pepaya memberikan khasiat sebagai penurun demam, penambah nafsu makan, melancarkan haid dan meredakan nyeri. Penelitian ini bertujuan untuk mengetahui ada tidaknya efek analgesik dari ekstrak daun pepaya pada mencit dengan menggunakan metode rangsang panas.

Metode: Penelitian ini merupakan penelitian eksperimental dengan menggunakan 9 ekor mencit. Hewan ini dibagi dalam tiga kelompok dimana setiap kelompok terdiri atas 3 ekor mencit. Bahan uji yang dingunakan yaitu ekstrak daun pepaya, obat analgesik tramadol, dan aquades yang diberikan pada masing-masing kelompok. Pengamatan dilakukan selama 1 menit dengan menggunakan metode rangsang panas berupa penurunan respon menjilat dan atau melompat setelah perlakuan. Hasil: Terjadi penurunan respon mencit menjilat kaki dan atau melompat terhadap rangsang panas yang diberikan setelah pemberian ekstrak daun pepaya. Kesimpulan: Ekstrak daun pepaya memiliki efek analgesik pada mencit.
\end{abstract}

Kata kunci: Analgesik, ekstrak daun pepaya, rangsang panas.

Tanaman obat sudah dikenal dan digunakan di seluruh dunia sejak beribu tahun yang lalu. Di Indonesia, penggunaan obat alami yang lebih dikenal sebagai jamu, telah meluas sejak zaman nenek moyang hingga kini dan terus dilestarikan sebagai warisan budaya. $^{1}$

Prinsip back to nature semakin populer pada era moderen ini. Orang meyakini hidup lebih sehat dengan pemanfaatan bahan-bahan alami. Demikian 
pun dalam dunia kesehatan, dengan kemajuan ilmu pengetahuan, justru banyak orang berpaling ke pengobatan tradisional. Efek samping obat-obatan kimia yang sering kali menimbulkan masalah baru yang tak kalah berat, menjadi salah satu pendorong berkembangnya pengobatan tradisional ini. $^{2}$ Dengan semakin meningkatnya kesadaran tersebut, risetriset ilmiah pun kini semakin banyak diarahkan pada bahan-bahan alami. Obatobatan herbal atau jamu yang diproses secara moderen dan didukung hasil riset pun semakin banyak tersedia. ${ }^{3}$

Salah satu jenis tanaman obat yang sering digunakan yaitu pepaya (Carica papaya L). Pepaya merupakan buah yang banyak dikonsumsi dan termasuk buah cepat masak setelah dipanen, tumbuh pada tanah lembab yang subur dan tidak tergenang air. Buah, bunga, dan daun muda dapat dimakan. ${ }^{4}$

Khasiat buah pepaya sebagai pelancar pencernaan, menstabilkan panas tubuh, obat luka lambung, menguatkan lambung dan antiscorbut. Buah papaya setengah matang digunakan sebagai pelancarkan urine, melancarkan air susu ibu (ASI) dan abortivum. Daun pepaya memberikan khasiat sebagai penurun demam, penambah nafsu makan, melancarkan haid dan meredakan nyeri (analgesik). ${ }^{2,5}$

Berdasarkan data yang didapat, penulis tertarik untuk melakukan pengujian untuk memperoleh data ilmiah tentang ada atau tidaknya potensi analgesik pada daun pepaya.

\section{METODE PENELITIAN}

Penelitian ini menggunakan metode eksperimental yang dilakukan di laboratorium Farmakologi dan Terapi Fakultas Kedokteran UNSRAT Manado. Penelitian dilakukan pada bulan Oktober 2012 sampai bulan Januari 2013. Penelitian ini menggunakan hewan uji yaitu mencit sebanyak 9 ekor. Hewan ini dibagi dalam 3 kelompok dimana setiap kelompok terdiri atas 3 ekor mencit, yaitu kelompok kontrol negatif, kelompok kontrol positif dan kelompok eksperimen yang diberikan ekstrak daun pepaya.

\section{Alat}

Alat-alat yang digunakan dalam penelitian yaitu timbangan analitik, oven, blender,, kain penyaring, kertas saring Whatman no.1, stopwatch, vortex, tabung reaksi, gelas beker, cawan petri, gelas ukur, mikropipet, semprit injeksi $1 \mathrm{ml}$, NGT (Nasogastric Tube) pediatri no.3,5 dan water bath.

\section{Bahan}

Bahan yang digunakan dalam penelitian yaitu daun pepaya Bangkok muda yang masih segar, aquades, obat analgesik (tramadol) $50 \mathrm{mg}$ dan alkohol $70 \%$.

Ada beberapa hal yang perlu disiapkan dan dilakukan dalam penelitian ini, seperti pembuatan ekstrak daun pepaya, penyiapan hewan uji, penyiapan larutan ekstrak dan larutan pembanding, pengujian efek analgesik dan lain-lain;

\section{Cara pembuatan ekstrak daun pepaya}

Daun pepaya yang telah diambil dikeringkan dalam oven dengan suhu $37^{\circ} \mathrm{C}$ selama \pm 5 hari. Daun pepaya yang telah kering kemudian dihaluskan dengan blender sampai didapatkan tepung daun pepaya. Tepung daun pepaya ditimbang $100 \mathrm{mg}$, kemudian direndam dengan 1000 ml alkohol 70\% selama 5 hari dimana terlindung dari sinar cahaya. Selama perendaman setiap hari dilakukan pengadukan selama 15 menit. Setelah direndam selama 5 hari, larutan disaring dengan kain penyaring. Hasil penyaringan kemudian disaring lagi dengan kertas saring whatman no.1.Hasil dari filtrasi penyaringan ditempatkan dalam cawan petri untuk kemudian diuapkan dalam oven dengan suhu $37^{\circ} \mathrm{C}$ sampai didapatkan ekstrak pekat. Ekstrak inilah yang digunakan dalam penelitian.

\section{Penyiapan hewan uji}


Penelitian ini menggunakan hewan uji yang yaitu mencit betina. mencit yang digunakan sebanyak 9 ekor yang dibagi dalam 3 kelompok, dimana setiap kelompok terdiri dari 3 ekor mencit. Mencit dipuasakan terlebih dahulu selama \pm 11 jam, lalu ditimbang sebelum diberikan perlakuan.

\section{Penyiapan larutan ekstrak}

Ekstrak daun pepaya sebanyak 1 gram dimasukkan kedalam tabung reaksi ditambah $10 \mathrm{ml}$ aquades. Diaduk hingga homogen. Diambil sebanyak $0,5 \mathrm{ml} / 20 \mathrm{~g}$ dengan semprit $1 \mathrm{ml}$ untuk diberikan kepada tiap hewan uji.

\section{Penyiapan larutan obat pembanding}

Sebagai kontrol positif digunakan obat analgesik tramadol dosis maksimal 100mg/50kgBB. Untuk dosis yang digunakan pada mencit dengan berat badan rata-rata 20 gram. Perhitungan dosis menggunakan dosis konversi dimana untuk mencit 20 gram pada manusia $70 \mathrm{~kg}$ yaitu 0,0026 (Laurance \& Bacharach: 1964)

$$
\begin{aligned}
& \text { Dosis konversi: } \\
& 100 \times 0,0026=0,26 \mathrm{mg} \\
& \underline{50 \mathrm{~kg} \times 0,26=0,18 \mathrm{mg}} \\
& 70 \mathrm{~kg}
\end{aligned}
$$

0,18 mg tramadol dilarutkan dengan akuades hingga diperoleh $0,5 \mathrm{ml}$ yang akan diberikan pada mencit.
Pemberian zat uji diberikan secara oral dengan menggunakan semprit $1 \mathrm{ml}$ dan NGT pediatrik no.3,5.

\section{Pengujian efek analgesik}

Mencit dimasukkan kedalam gelas beker yang telah dipanaskan dalam water bath yang berisi air dengan suhu $55^{\circ} \mathrm{C}$. Dilakukan pengamatan pada respon mencit yaitu dengan melihat berapa kali mencit menjilat kakinya dan atau melompat. Pengamatan dilakukan selama 1 menit. Setelah itu mencit diberikan zat yang akan diuji dan larutan pembanding (obat tramadol dan aquades). Kemudian mencit diistirahatkan untuk diamati kembali. Dilakukan pengamatan respon dari mencit dimana dilakukan pada menit ke 30, 60, 90, dan 120 setelah pemberian zat uji dan larutan pembanding, dengan lama pengamatan 1 menit. Pengamatan dilakukan sebanyak 5 kali, yaitu sebelum pemberian zat uji, menit ke 30, 60, 90 dan 120 setelah pemberian zat uji.

\section{Penyajian Analisis data}

Data hasil pengamatan dikumpulkan dan disajikan dalam bentuk tabel dan grafik.

\section{HASIL PENELITIAN}

Data hasil penelitian ini diperoleh dari 3 kelompok mencit yang masing-masing

\begin{tabular}{|c|c|c|c|c|c|c|c|c|c|c|c|c|c|c|c|}
\hline \multirow{4}{*}{ Kelompok } & \multicolumn{15}{|c|}{ Waktu } \\
\hline & \multirow{2}{*}{\multicolumn{3}{|c|}{$\begin{array}{c}\text { Sebelum } \\
\text { perlakuan }\end{array}$}} & \multicolumn{9}{|c|}{ Setelah perlakuan } & \multirow{2}{*}{\multicolumn{3}{|c|}{ 120' }} \\
\hline & & & & \multicolumn{3}{|c|}{$30^{\prime}$} & \multicolumn{3}{|c|}{$60^{\prime}$} & \multicolumn{3}{|c|}{ 90' } & & & \\
\hline & $\mathrm{L}$ & $\mathrm{J}$ & $\mathrm{T}$ & $\mathrm{L}$ & $\mathrm{J}$ & $\mathrm{T}$ & $\mathrm{L}$ & $\mathrm{J}$ & $\mathrm{T}$ & $\mathrm{L}$ & $\mathrm{J}$ & $\mathrm{T}$ & $\mathrm{L}$ & $\mathrm{J}$ & $\mathrm{T}$ \\
\hline Mencit 1 & - & 36 & 36 & - & 21 & 21 & 4 & 4 & 8 & 2 & 4 & 6 & 1 & 7 & 8 \\
\hline Mencit II & - & 53 & 53 & - & 36 & 36 & - & 20 & 20 & - & 15 & 15 & - & 21 & 21 \\
\hline Mencit III & - & 44 & 44 & - & 23 & 23 & - & 27 & 27 & - & 22 & 22 & - & 22 & 22 \\
\hline Jumlah & & 33 & & & 80 & & & 55 & & & 43 & & & & 51 \\
\hline Rata-rata & & 44 & & & 27 & & & 18 & & & 14 & & & & 17 \\
\hline
\end{tabular}
kelompok terdiri dari 3 ekor mencit.

\section{Cara pemberian Zat uji}

Tabel 1. Hasil Pengamatan Respon Mencit Kelompok Kontrol Positif (Tramadol) 
Tabel 2. Hasil Pengamatan Respon Mencit Kelompok Kontrol Negatif (Aquades)

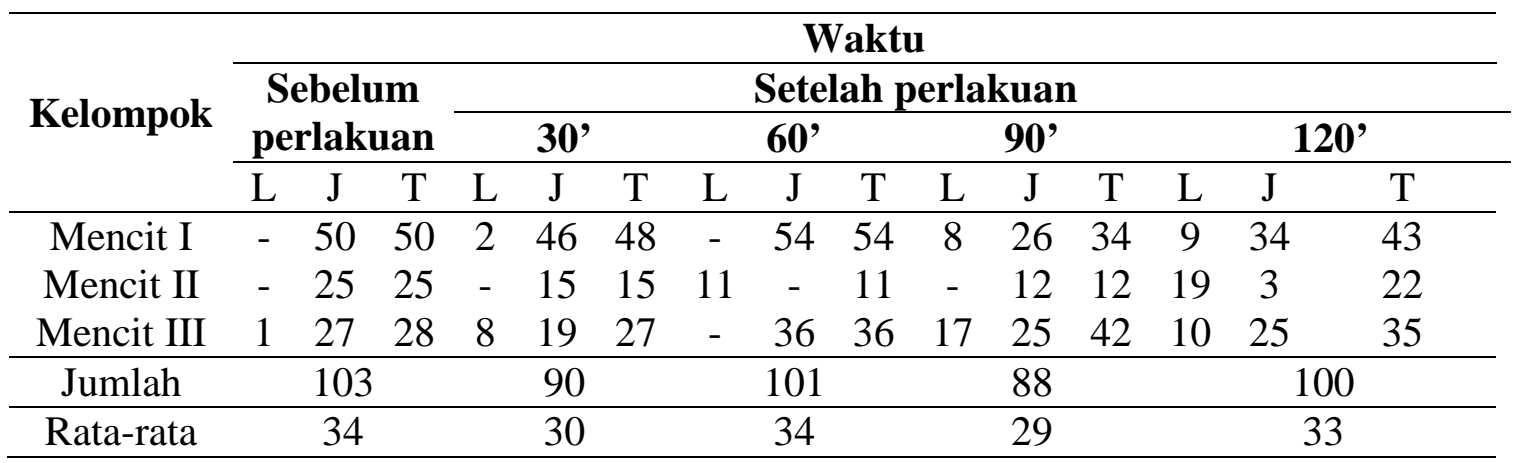

Ket : $\mathrm{L}=$ Lompat ; $\mathrm{J}=$ Jilat $; \mathrm{T}=$ Total

Pembulatan bilangan desimal: $<0,5=0$ dan $>0,5=1$

Tabel 3. Hasil Pengamatan Respon Mencit Kelompok Perlakuan Ekstrak Daun Pepaya

\begin{tabular}{|c|c|c|c|c|c|c|c|c|c|c|c|c|c|c|c|}
\hline \multirow{4}{*}{ Kelompok } & \multicolumn{15}{|c|}{ Waktu } \\
\hline & \multirow{2}{*}{\multicolumn{3}{|c|}{$\begin{array}{l}\text { Sebelum } \\
\text { perlakuan }\end{array}$}} & \multicolumn{12}{|c|}{ Sesudah perlakuan } \\
\hline & & & & \multicolumn{3}{|c|}{$30^{\prime}$} & \multicolumn{3}{|c|}{$60^{\prime}$} & \multicolumn{3}{|c|}{$90^{\prime}$} & \multicolumn{3}{|c|}{$120^{\prime}$} \\
\hline & $\mathrm{L}$ & $\mathrm{J}$ & $\mathrm{T}$ & $\mathrm{L}$ & $\mathrm{J}$ & $\mathrm{T}$ & $\mathrm{L}$ & $\mathrm{J}$ & $\mathrm{T}$ & $\mathrm{L}$ & $\mathrm{J}$ & $\mathrm{T}$ & $\mathrm{L}$ & $\mathrm{J}$ & $\mathrm{T}$ \\
\hline Mencit I & - & 35 & 35 & 2 & 16 & 18 & 9 & 2 & 11 & 1 & 25 & 26 & - & 30 & 30 \\
\hline Mencit II & 12 & 20 & 32 & 8 & 1 & 9 & 4 & - & 4 & 2 & - & 2 & 4 & - & 4 \\
\hline Mencit II & - & 52 & 52 & - & 45 & 45 & - & 20 & 20 & - & 12 & 12 & - & 12 & 12 \\
\hline Jumlah & & 119 & & & 72 & & & 35 & & & 40 & & & & \\
\hline Rata-rata & & 40 & & & 24 & & & 12 & & & 13 & & & & \\
\hline
\end{tabular}

Ket: L= Lompat; J= Jilat; T= Total

Pembulatan bilangan desimal: $<0,5=0$ dan $>0,5=1$

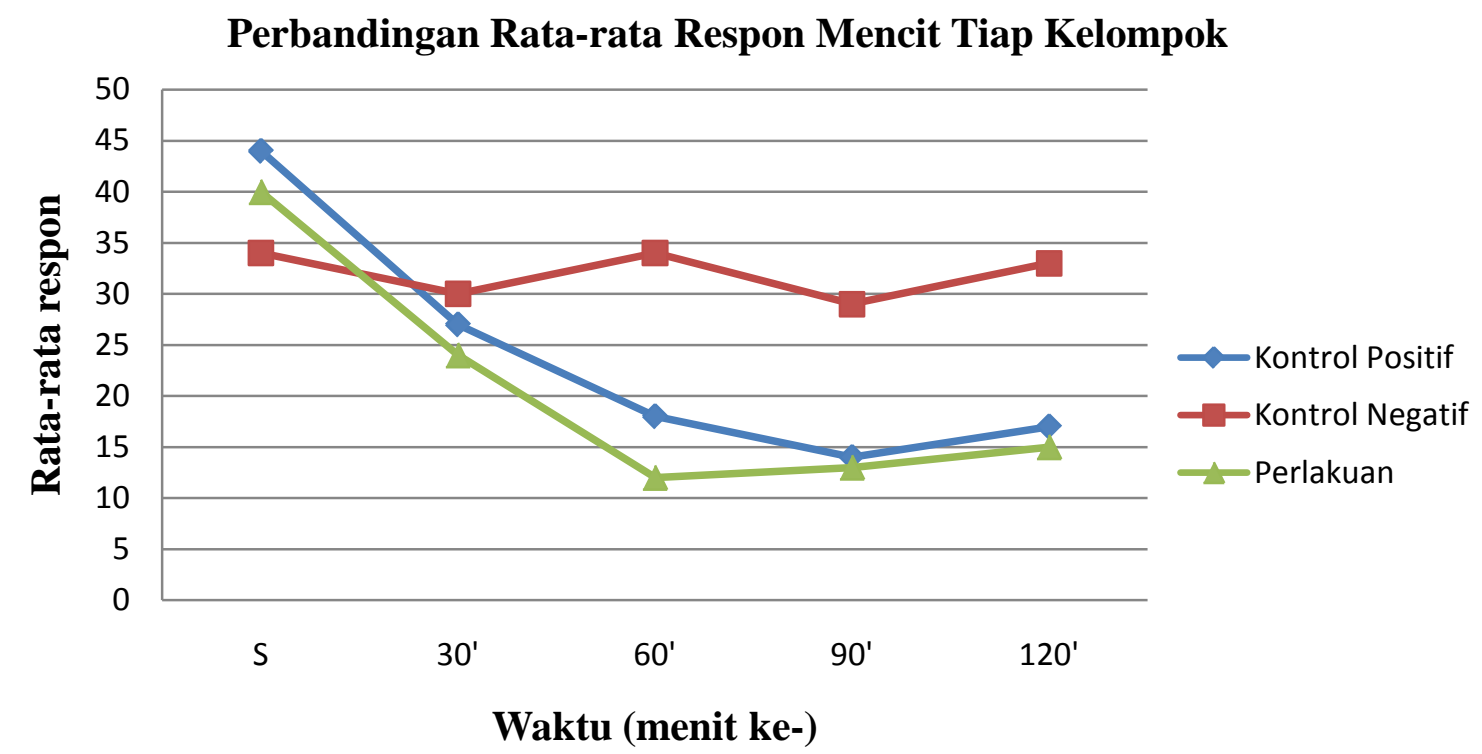

Gambar 1. Grafik perbandingan Rata-rata Respon Mencit Tiap Kelompok Ket: $\mathrm{S}=$ Sebelum perlakuan. 
Pada Tabel 1 di atas, menunjukkan bahwa rata-rata jumlah respon mencit sebelum pemberian tramadol $44,3 \mathrm{kali}$ respon (dibulatkan menjadi 44 kali respon). pada menit ke-30 setelah pemberian obat tramadol, rata-rata jumlah respon menurun 26,6 kali respon (dibulatkan menjadi 27 kali respon), pada menit ke-60 18,3 kali respon dibulatkan menjadi 18 kali respon, pada menit ke-90 14,3 kali respon (dibulatkan menjadi 14 kali respon) dan pada menit ke-120 17 kali respon.

Pada Tabel 2 di atas, rata-rata respon mencit sebelum pemberian aquades 34,3 kali respon (dibulatkan menjadi 34 kali respon). pada menit ke-30 setelah pemberian aquades, rata-rata jumlah respon 30 kali respon, pada menit ke-60 33,6 kali respon (dibulatkan menjadi 34 kali respon), pada menit ke-90 29,3 kali respon (dibulatkan menjadi 29 kali respon) dan pada menit ke-120 33,3 kali respon (dibulatkan menjadi 33 kali respon).

Pada Tabel 3 di atas, terlihat rata-rata respon mencit sebelum pemberian ekstarak daun pepaya yaitu 39,6 kali (dibulatkan menjadi 40 kali respon). pada menit ke-30 setelah pemberian ekstrak daun pepaya, rata-rata jumlah respon menurun menjadi 24 kali respon, pada menit ke-60 11,6 kali respon (dibulatkan menjadi 12 kali respon), pada menit ke-90 13,3 kali respon (dibulatkan menjadi 13 kali respon) dan pada menit ke-120 15,3 kali respon (dibulatkan menjadi 15 kali respon).

Pada Gambar di atas terlihat rata-rata respon mencit kelompok kontrol positif dan kelompok perlakuan mengalami penurunan setelah perlakuan dibandingkan sebelum perlakuan, sedangkan respon rata-rata mencit kelompok negatif cenderung stabil.

\section{BAHASAN}

Dalam penelitian ini telah dilakukan uji efek analgesik dengan menggunakan ekstrak daun pepaya sebagai kelompok perlakuan. Obat tramadol sebagai kontrol positif dan aquades sebagai kontrol negatif. Sebelum diberikan zat uji, terlebih dahulu diamati jumlah respon hewan uji terhadap rangsang nyeri (menjilat dan atau melompat), supaya dapat dilihat perbandingan antara sebelum dan sesudah pemberian zat uji.

Berdasarkan hasil yang didapatkan melalui pengujian 3 ekor mencit yang diberikan ekstrak daun pepaya terlihat penurunan jumlah respon rata-rata rangsangan nyeri dari mencit setelah diberi perlakuan dibandingkan sebelum diberi perlakuan. Dari Tabel terlihat bahwa pada menit ke-30 setelah pemberian ekstrak daun pepaya dari 40 kali respon menjadi 24 kali respon. Jumlah respon rata-rata ini terus berkurang hingga pada menit ke-60 menjadi 12 kali respon, menit ke-90 menjadi 13 kali respon dan menit ke-120 menjadi 15 kali respon. Berdasarkan hasil tersebut, didapatkan bahwa pemberian ekstrak daun pepaya pada mencit menunjukkan adanya efek analgesik. Efek analgesik mulai terlihat pada menit ke-30 setelah perlakuan dan tetap memperlihatkan efek analgesik sampai menit ke-90. Efek analgesiknya mulai menurun pada menit ke-120.

Hasil yang didapatkan pada kelompok kontrol positif yang diberi obat tramadol, terjadi penurunan jumlah respon rata-rata mencit terhadap rangsangan nyeri pada menit ke-30 setelah pemberian obat tramadol dari 44 kali respon menjadi 27 kali respon. Kemudian terus turun pada menit ke 60 menjadi 18 kali respon, pada menit ke 90 menjadi 14 kali respon, dan pada menit ke 120 menjadi 17 kali respon. Efek analgesik pada kelompok kontrol positif yang diberi obat tramadol mulai terlihat pada menit ke 30 sampai menit ke 120. Puncak efek analgesik tramadol pada menit ke-90.

Dari hasil pengujian yang didapat bahwa efek analgesik dari ekstrak daun pepaya dan tramadol sudah mulai terlihat pada menit ke 30. Efek analgesik maksimal dari ekstrak daun pepaya pada menit ke 60, kemudian di menit ke 90 dan 120 efek analgesiknya mulai menurun, sedangkan pada kontrol positif yang diberi obat tramadol efek maksimal pada menit ke 90 kemudian di menit ke 120 efek 
analgesiknya mulai turun, walaupun begitu efek analgesik dari kedua bahan uji ini masih tetap terlihat.

Dari keseluruhan hasil yang didapatkan terlihat bahwa dalam penelitian ini efek yang ditimbulkan oleh ekstrak daun pepaya sedikit lebih baik dari pada tramadol, pada mencit. Hal ini kemungkinan disebabkan oleh perbedaan dosis yang diberikan dimana dosis ekstrak daun pepaya 1 gram (dosis yang diberikan dalam penelitian terdapat $50 \mathrm{mg}$ dalam 0,5 $\mathrm{ml})$ lebih besar dari pada dosis tramadol (dosis yang diberikan 0,18 mg dalam 0,5 $\mathrm{ml}$ ). Pemberian dosis ekstrak daun pepaya yang tinggi dari tramadol dalam penelitian ini dimaksudkan untuk mendapatkan efek analgesik dari ekstrak daun pepaya.

Data hasil pengamatan pada kelompok kontrol negatif yang diberikan aquades terlihat bahwa respon rata-rata hewan uji terhadap rangsangan nyeri sebelum pemberian aquades 34 kali respon, pada menit ke 30 setelah pemberian aquades menjadi 30 kali respon, pada menit ke 60 menjadi 34 kali respon, pada menit ke 90 menjadi 29 kali respon, dan pada menit ke 120 menjadi 33 kali respon. Berdasarkan hasil yang didapatkan terlihat bahwa respon rata-rata mencit sebelum dan sesudah pemberian aquades, tidak terdapat perbedaan yang signifikan dan cenderung respon yang diberikan stabil sehingga dapat disimpulkan aquades tidak memiliki efek analgesik.

Dari hasil penelitian terlihat bahwa tidak semua mencit menunjukkan respon yang sama walaupun dalam satu kelompok perlakuan. Respon yang berbeda-beda ini kemungkinan disebabkan oleh banyaknya faktor yang mempengaruhi. Faktor yang mempengaruhi perbedaan respon yaitu faktor internal dan eksternal. Faktor internal yaitu perbedaan spesies, genetik, seks, dan umur, sedangkan faktor eksternal yaitu makanan dan lingkungan. ${ }^{20}$

\section{SIMPULAN}

Berdasarkan hasil penelitian uji efek analgesik ekstrak daun pepaya pada mencit, maka dapat disimpulkan bahwa ekstrak daun pepaya memiliki efek analgesik pada mencit.

\section{SARAN}

Perlu dilakukan penelitian lebih lanjut untuk identifikasi senyawa yang berkhasiat analgesik pada daun pepaya. Perlu dilakukan penelitian efek analgesik ekstrak daun pepaya dengan menggunakan dosis yang berbeda dan metode yang berbeda pula. dan perlu dilakukan penelitian dengan menggunakan hewan uji yang lebih banyak dan waktu yang lebih lama.

\section{UCAPAN TERIMA KASIH}

Ucapan terima kasih disampaikan pada Prof. dr. Jimmy Posangi, MSc, PhD, SpFK dan dr. P. M. Wowor, MKes, SpFK, dan pada semua pihak yang baik secara langsung maupun tidak langsung telah menumbuhkan idea atau gagasan dalam pemikiran penulis sehingga dapat menyelesaikan artikel ini.

\section{DAFTAR PUSTAKA}

1. Harmanto N, Subroto M A. Pilih Jamu dan Herbal Tanpa Efek Samping. Jakarta: PT Elex Media Koputindo; 2007. h. 15.

2. Thomas A.N.S. Tanaman Obat Tradisional 1. Yogyakarta: kanisius; 2000. h. 11.

3. Apriyanti M. 10 Tanaman Obat Paling Berkhasiat \& Paling Dicari. Yogyakarta: Pustaka Baru Pres. h. 2.

4. Damayanti D, Sudarsono, Mariska I, Herman M. Regenerasi Pepaya melalui Kultur In Vitro. jurnal AgriBiogen: 2007.Vol. 3(2), h. 49.

5. Dalimartha S. Atlas Tumbuhan Obat Indonesia Jilid 6. Jakarta: Pustaka Bunda; 2009. h. 122-23.

6. Gibson GG, Skestt P. Pengantar Metabolisme Obat. Jakarta: Penerbit Universitas Indonesia Press; 2006. h. 12056. 